This is an Open Access article, distributed under the terms of the Creative Commons Attribution licence (http://creativecommons.org/licenses/by/4.0/), which permits unrestricted re-use, distribution, and reproduction in any medium, provided the original work is properly cited.

\title{
Production or Consumption? Glass Beads from the Roman Villa of Aiano, Tuscany
}

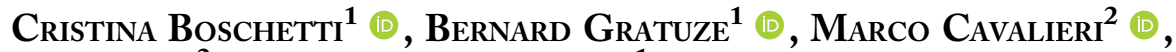 \\ SARA LeNZI ${ }^{2}$ (1) AND Nadine SchibILle ${ }^{1}$ \\ ${ }^{1}$ Institut de Recherche sur les Archéomatériaux, CNRS/Université d'Orléans, France \\ ${ }^{2}$ Institut des Civilisations, Arts et Lettres, Université Catholique de Louvain \\ (UCLouvain), Belgium
}

\begin{abstract}
Excavations in the Roman villa of Aiano yielded twenty glass beads, a pendant, and a glass-recycling furnace, originally interpreted as a bead workshop. This article re-assesses the evidence of bead making in light of new data obtained thanks to recent progress in archaeological glass studies. A detailed study of the typology, technology, and chemical composition of the beads clearly excludes local production. Instead, two different forming techniques, four different base glasses (Roman, HIMT, Foy 2.1 and Foy 2.1/HIMT), and numerous colouring and opacifying materials point to a well-established and extensive network of the Roman bead trade, in which Aiano evidently participated. The majority of the beads can be related to the monumentalization of the villa in the fourth to fifth century $A D$ and represent a sample of the ornaments worn by its inhabitants.
\end{abstract}

Keywords: Roman glass beads, glass recycling workshop, Late Antique Tuscany, Roman glass trade, Roman villa

\section{INTRODUCTION}

Glass beads adorning the body were some of the earliest vitreous materials ever produced in the late fourth millennium $\mathrm{BC}$ (Moorey, 1994: 190-92). They became increasingly popular during the Late Bronze Age, when glass production began more systematically, and beads were recovered in substantial numbers from temple and palatial complexes in Mesopotamia and Egypt (Shortland, 2000: 81; Hodgkinson, 2017: 75-105). In the eastern Mediterranean, the products of glass workshops were diverse and beads were made alongside vessels, inlays, and figurines (Shortland, 2000: 81). In this early period, beads were important commodities, recognized for qualities that went beyond their aesthetic appeal (Nightingale, 2008). The outstanding symbolic value attributed to beads is clearly reflected in the great distances covered by their trade and their role in rituals. For example, in the fourteenth century BC, thousands of Egyptian glass beads were transported by two ships sunk off the Anatolian coast at Uluburun and 
Cape Kylidonia (Pulak, 1998; Jackson \& Nicholson, 2010). At this time, Egyptian and Mesopotamian beads travelled as far as Scandinavia, where they have been recovered in Danish burials (Varberg et al., 2015). In Mesopotamia (Moorey, 1994: 192; Feldman, 2006), Mycenaean Greece (Nightingale, 2008, with earlier references), and in Egypt (Müller, 2018, with references), beads were buried in the foundation deposits of temples, palaces, and tombs. In Egypt and Nubia, the use of beads in building rituals continued without interruptions for nearly two millennia, illustrated by the evidence from Ptolemaic and Roman temples (ThenObłuska, 2017), and Coptic churches as late as the seventh century $\mathrm{AD}$ (ThenObłuska, 2013).

In the eleventh to tenth century BC, when glassmaking appeared for the first time in the western Mediterranean, beads were the only products manufactured in the workshops of Frattesina and other sites identified in the Po valley (Towle et al., 2001). These western productions remained isolated and probably ceased with the decline of Frattesina at the end of the tenth century BC (Cavazzuti et al., 2019). Judging by some exceptional eighth-century BC black beads documented in Spain, Anatolia, Slovakia, and Italy (Conte et al., 2016), some western glass making and glass working may have continued into the Iron Age. The dynamics of bead production and trade during the Iron Age are still insufficiently investigated, and the archaeological record lacks identified bead-making workshops. However, the varied compositional makeup of Iron Age bead assemblages and their typological variability seem to reflect a lively international bead trade (Conte et al., 2016, 2019). Glass beads were highly popular at that time and they were strung on necklaces or bracelets, but they were also sewn onto clothing as evidenced by finds in elite burials excavated in central Italy and Greece (Gleba, 2017).

Until the end of the Iron Age, glass beads were formed exclusively by winding, a simple process involving coiling and tooling a mass of soft glass around a metallic rod (mandrel). Winding was practiced in all the cultures that produced glass beads, in Asia, Europe, and Africa. The Hellenistic period, from the last decades of the fourth century BC, represents a phase of technological innovation for bead making, especially in Egypt and Greece where new and highly specialized techniques were developed. The identification of these forming techniques is relevant, because technological and chemical studies show a link between specialized forming techniques and the area of production (Boschetti et al., 2020a, with references). A first innovation in Hellenistic bead making is the invention of drawing and segmenting. Segmented beads were formed from hollow glass rods that were divided into individual beads with the help of shaping thongs or moulds with indentations (Spaer, 1993). This technique was popular in a variant known as sandwich-gold glass, where a gold leaf was sandwiched between two layers of colourless glass (Spaer, 1993). At the end of the third century BC, a workshop in Rhodes constitutes the first archaeological proof of the production of beads using this technique, which probably originated in Egypt in the fourth century BC (Weinberg, 1983; Spaer, 1993). Another innovation in Hellenistic Egypt is the mosaic technique, a variant of winding, in which sections of polychrome canes are gathered around the mandrel. This mosaic technique was originally used to make inlays (Bianchi, 1983) and beads from the second century BC onwards (Liu et al., 2017). Evidence for the production of wound beads was found in a second-century BC context at Delos (Nenna, 1993). Currently Roman 
beads are poorly served by research: a comprehensive typology of Roman beads does not exist, and technological studies are lacking entirely. Two fourth- to sixthcentury $\mathrm{AD}$ workshops identified in Alexandria, where segmentation and winding were practised, are currently the only archaeologically attested contexts of bead making for the Roman and Late Antique period (Rodziewicz, 1984; RifaAbou El Nil \& Calligaro, 2020). There is a complete absence of indicators of bead making in the Italian peninsula, in line with the general lack of evidence for Roman glass working, particularly for the Republican and early Imperial periods (Boschetti, 2020). Egyptian mosaic and segmented beads continued to circulate throughout the Mediterranean, but there is no comprehensive map of their distribution (Then-Obłuska, 2018).

Thanks to the identification of bead winding workshops in Scandinavia, Ireland, and the Netherlands, it is clear that glass beads were manufactured in Europe during the Migration period (Boschetti et al., 2020a, with references). Egyptian mosaic and segmented beads were nonetheless still sought after and traded as far as Scandinavia (Callmer, 1977) and the Caucasus (Bezborodov, 1959). Beads made with a Mesopotamian compositional signature also appear on the European market in the seventh century $\mathrm{AD}$, but their provenance is still unclear (Boschetti et al., 2020a, with references). The Migration period is a prolific time for glass beads, which were used for jewellery as well as for beautifying textiles (Juwig, 2010; Pion \& Gratuze, 2016). Interestingly, the tiny glass beads used for decorating clothes were manufactured in India (Pion \& Gratuze, 2016; Boschetti et al., 2020a), using a complex technique involving drawing, cold cutting, and hot polishing (Francis, 1990). Asian beads circulated in Europe until the end of the sixth century, but the origins of this commerce are obscure. A detailed study of Hellenistic and Roman beads would be helpful to establish the beginning of this trade, which could date back to as early as the end of the third century BC (Francis, 1988).

Against this background of limited archaeological evidence and fragmentary studies, the discovery in 2008 of a glassrecycling furnace and seven glass beads in the Roman villa of Aiano in Tuscany was enthusiastically identified as a workshop for the production of beads dating to the Migration period, allegedly the only one in Italy (Cavalieri \& Giumlia-Mair, 2009). The furnace dates to the sixth century $\mathrm{AD}$, when the abandoned Roman building was reoccupied to host artisanal activities (Deltenre \& Orlandi, 2016). The discussion of the chemical composition of four beads and a group of tesserae and other glasses from Aiano in 2009 was limited to the identification of colourants and opacifiers (Cavalieri \& Giumlia-Mair, 2009). Over the last decade, Roman and Late Antique glass studies have improved significantly; it is now possible to identify different base glasses and trace their place of origin by the heavy elements introduced as impurities in the silica source (Freestone et al., 2018, with references). New data obtained during the archaeological campaigns at Aiano since 2009 cast doubt on the identification of bead production in Aiano. After ten years of research, the building sequence is now clear and there are enough elements to understand the relationship between the beads found at Aiano and the history of this complex building.

Here we present a re-assessment of the Aiano beads, examining all the specimens recovered between 2005 and 2019 and discussing their depositional history, typology, forming technique, and chemical composition. The main objective is to 
place the Aiano beads in a broad Mediterranean and European context and to evaluate critically their previous interpretation as local products. We aim not only to clarify the meaning and function of the beads in Aiano, but also to reflect on the dynamics that regulated the production and circulation of glass beads between Late Antiquity and the early Middle Ages.

\section{The Roman Villa of Aiano}

The Roman villa of Aiano is located in present-day Tuscany, in the district called Tuscia et Umbria since the beginning of the fourth century $\mathrm{AD}$ (Figure 1). The building occupies a central position in the Elsa river valley, on top of a plateau created by a palaeo-landslide. The structures, investigated between 2005 and 2019 , consist of a large central hall with three apses, surrounded by a corridor with five apses or lobes $(\mathrm{N})$. The hall was preceded on the south side by a quadrangular vestibule connected to a wide corridor oriented north-south (R), which looked onto three rectangular rooms on the west side $(\mathrm{A}, \mathrm{B}, \mathrm{C})$. The eastern wing was organized as a sequence of small rooms. During the sixth-century AD reoccupation of the villa, this sector housed a series of workshops dedicated to the collection and recycling of materials taken from the building. The principal feature of the building's north wing is a large rectangular hall with four pilasters that opened on the east side onto an open area framed by a porch $(\mathrm{V})$. The building was occupied from the end of the third century to the middle of the seventh century $\mathrm{AD}$ and the analysis of the features identified six major phases (Cavalieri, 2020; Cavalieri \& Peeters, 2020) (Figure 2, Table 1).

The earliest phase (Phase 1) survives only in rooms $\mathrm{A}$ and $\mathrm{B}$, in the south- western sector of the site. During Phase 2, the building twice underwent monumental renovations. The first intervention, datable to the second half of the fourth century, was the creation of a hall with six apses, surrounded by a corridor with five lobes, opening to the south onto a rectangular antechamber. The hall probably functioned as a passageway leading to the northern sector of the villa. In a second phase, possibly a few decades later, the former project was radically modified. Three of the six apses of the main hall were demolished, creating a space for three rectangular rooms. The hall was paved with an opus signinum floor decorated with tesserae, which is still in situ. This intervention was crucial in defining the function of the rooms and transforming the central hall into a monumental hall.

At the end of the fifth century (Phase 3), the villa was abandoned, and parts of the structures collapsed. After a relatively short period of abandonment, the site was reoccupied at the beginning of the sixth century. The building now served various productive activities, where all the materials used in the villa (marble, glass, lead, bronze, bricks) were systematically collected and recycled (Deltenre \& Orlandi, 2016). These activities were responsible for the fragmentation and dispersal of the residual material from the earlier phases of the building. At the present stage of the archaeological investigations, it is possible to identify the south and north wing as the two main sectors of artisan activity. Activities in the south wing are clearly visible archaeologically and include a smithy (Room B) and other pyrotechnological activities (Area 5000) (Cavalieri, 2013: 302). The north wing housed a combination of pyrotechnological activities difficult to interpret and service spaces. Interestingly, the rooms surrounding the three-apsidal hall were characterized by a 


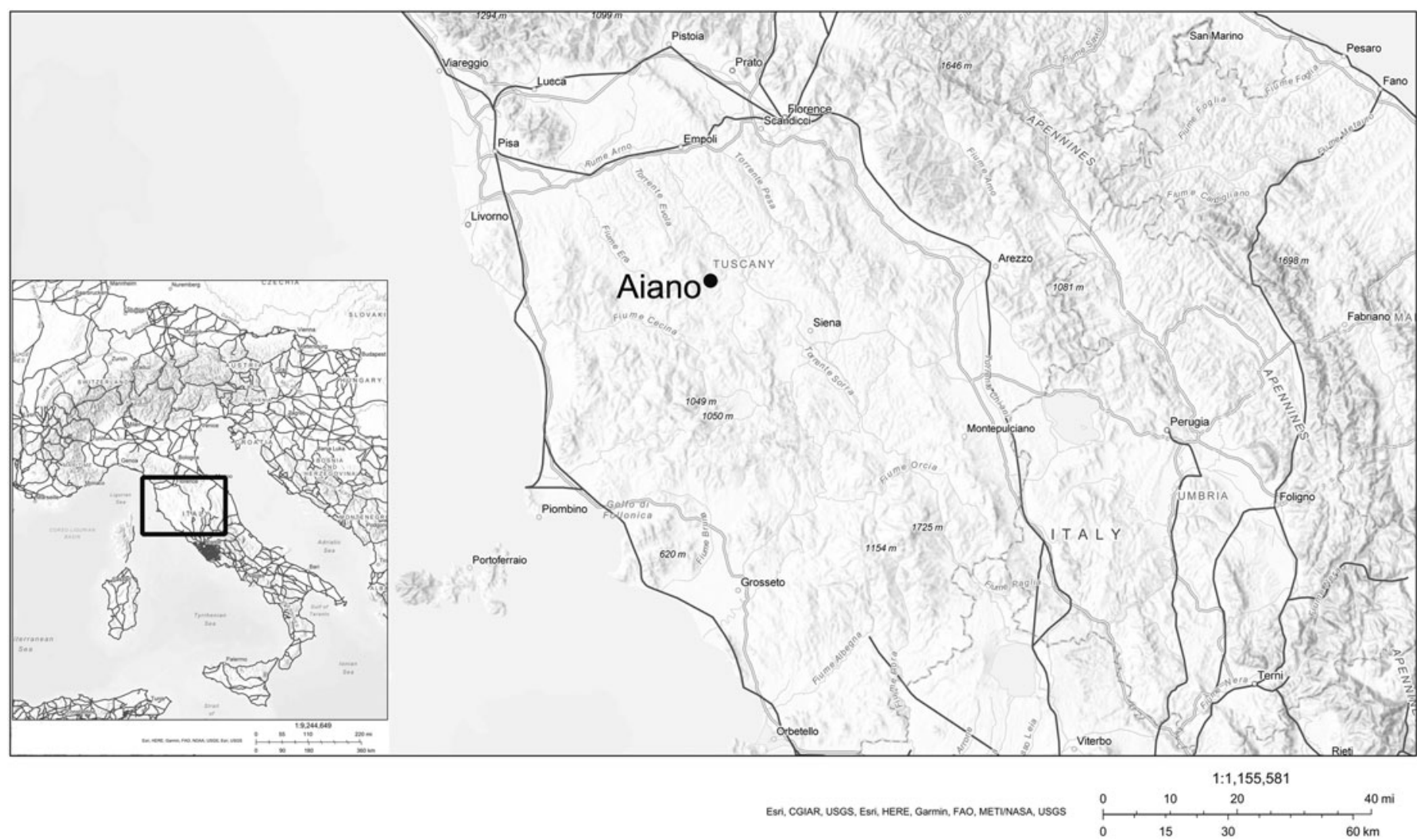

Figure 1. Map of Tuscany, with Aiano (Adapted from cartography of DARMC https://darmc.harvard.edu/). 


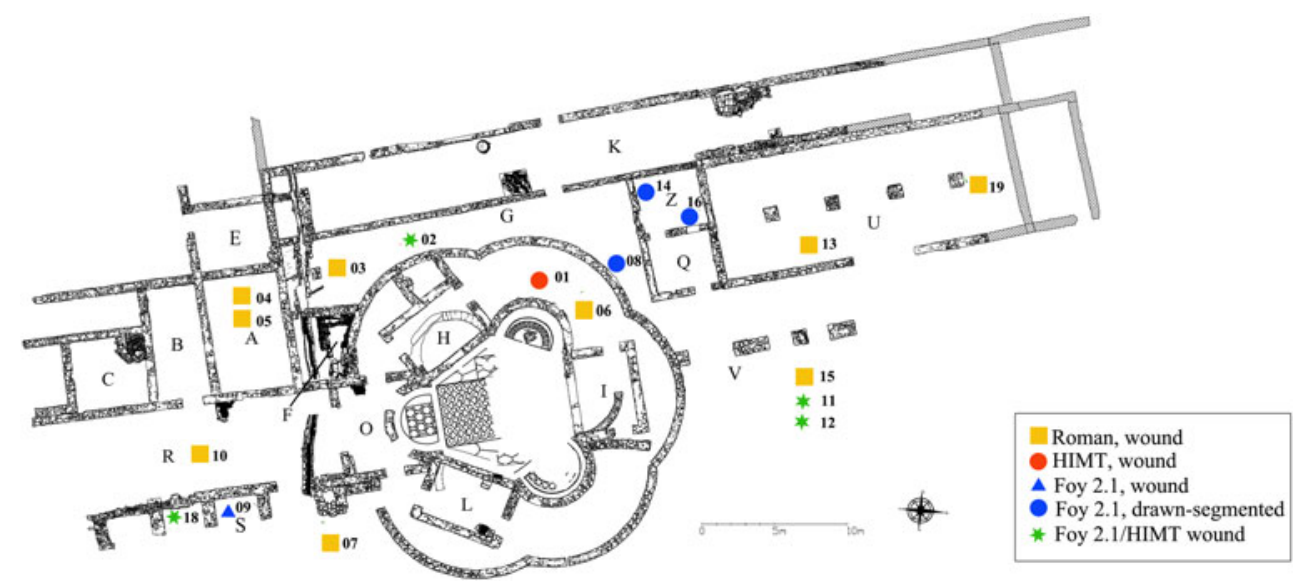

Figure 2. Plan of the Aiano villa, after the 2018 excavation campaign, showing the distribution of the beads, divided by compositional group and forming technique (polychrome beads are classified according to the base glass used for the body) (adapted from a drawing by A. Novellini). (C UCLouvain.

Table 1. Chronological phases of the Aiano villa.

\section{Phase Chronology}

1 End of third century-first half of fourth century $\mathrm{AD}$

2 Second half of fourth century-second half of fifth century $\mathrm{AD}$

3 End of fifth century-first half of sixth century $\mathrm{AD}$

4 Second half of the sixth-middle of seventh century $\mathrm{AD}$

5 From the second half of seventh century AD

6 Modern era

high level of specialization: Room I was dedicated to the transformation of copper alloys, activity in Room $\mathrm{H}$ was probably linked to a nearby pottery kiln (Room F), while Room L yielded traces of gold working (Cavalieri et al., 2009; Cavalieri \& Giumlia-Mair, 2009; Cavalieri, 2013; Deltenre \& Orlandi, 2016). Particularly relevant for our present study is the discovery of a glass-recycling furnace in Room O. The furnace was used to work both cullet and glass mosaic tesserae, an activity clearly connected to Room A, where 6000 mosaic tesserae, partially altered by heat, were found. In this space, the cullet was stored before being recycled, and two pits were used for roasting and washing the tesserae to remove the mortar. Hundreds of fragmentary glass inlays were recovered from a series of small open spaces located next to the corridor (R), probably similarly dedicated to the storage of glass cullet (Cavalieri et al., 2016).

The function of the spaces in the north wing is more difficult to determine, but it is clear that Room U served as storage for fragments of floor mosaics for re-use (Cavalieri et al., 2013: 538, 543, figs 2-3). Part of this space also served the daily needs of the craftsmen. There were, for example, a series of structures for cooking and possibly for baking in corridor K. In short, throughout most of the sixth century, the villa at Aiano was an openair workshop devoted to collecting and transforming materials spoliated from the abandoned building. Similar multiactivity recycling workshops are documented in other Late Antique Tuscan sites (Sebastiani, 2016: 66), glass-recycling, for instance, is clearly documented in Spolverino (Sebastiani \& Derrick, 2020). 
All productive activities came to an end and the building was finally abandoned during Phase 4. The decline of the villa is evident from the second half of the seventh century (Phase 5) in the form of collapsed walls almost everywhere in the building. The only traces of occupation are the tombs of two individuals, possibly pilgrims, buried in rooms Q and Z. Modern agricultural activities are responsible for damaging the features (Phase 6).

\section{The Glass Beads from Aiano: Deposition And Distribution}

Twenty glass beads and one pendant were retrieved during the excavation campaigns conducted at Aiano from 2005 to 2019. The beads were all deposited in backfills formed between the sixth and the seventh century, when the artisanal activities came to an end and the area was abandoned (Table 1 and Supplementary Material Table S1). These backfills are characterized by a high degree of residuality. Finds dating to the second half of the fourth century, the time of the monumental renovation of the villa, are accompanied by late fifth- to seventh-century material. Earlier material is less frequent. The beads were scattered across the vast area occupied by the villa, without any significant clustering, and no bead was deposited in fills associated with the glass-recycling furnace excavated in the ambulatio of the five-lobed hall (Room O). An important concentration of glass-working waste was retrieved from Area 7000, located immediately outside the central hall and interpreted as a zone used as dump, collecting the waste generated by the craft activities.

The visual examination of all the glass finds from Aiano ascertained that there is no evidence that could be linked to bead working, such as tools, glass canes, and/or failed beads. The beads are a small group of finished objects, which speaks against a productive site. Some fragments of a ceramic container with holes found near the furnace were described as a brazier used for bead making (Cavalieri \& Giumlia-Mair, 2009). This identification was based on the representation of a similar object in a Renaissance woodcut print entitled Der Glasser (Cavalieri \& Giumlia-Mair, 2009: 1026-27). A careful examination of the scene, however, reveals that the woodcut print does not actually depict a glass-working scene, but the assembly of a stained-glass window. Moreover, braziers are unsuitable for glass working and the object excavated in Aiano certainly had a different function. The glass-working waste from Area 7000 includes fragments of vessels and tesserae deformed by heat, fragments of refractory material with adhering glass, and masses of tooled coloured glass (Figure 3). These finds are evidence of the recycling of colourless and coloured glass, but it is impossible to ascertain whether this glass was shaped into new objects at Aiano or whether it was moved to secondary workshops as unprocessed glass. As documented during the fourth century $\mathrm{AD}$ at Aquileia (Boschetti et al., 2016) and during the ninth century at San Vincenzo al Volturno (Schibille \& Freestone, 2013), colourless glass was recycled and coloured by adding mosaic tesserae. A similar recycling process probably took place in Aiano, where the deposits associated with the furnace yielded an exceptional concentration of windowpanes and mosaic tesserae.

\section{Materials and Methods}

The technology for forming beads can be easily identified by visual examination and is the main criterion adopted to classify the beads from Aiano. All twenty beads and the pendant were selected for 


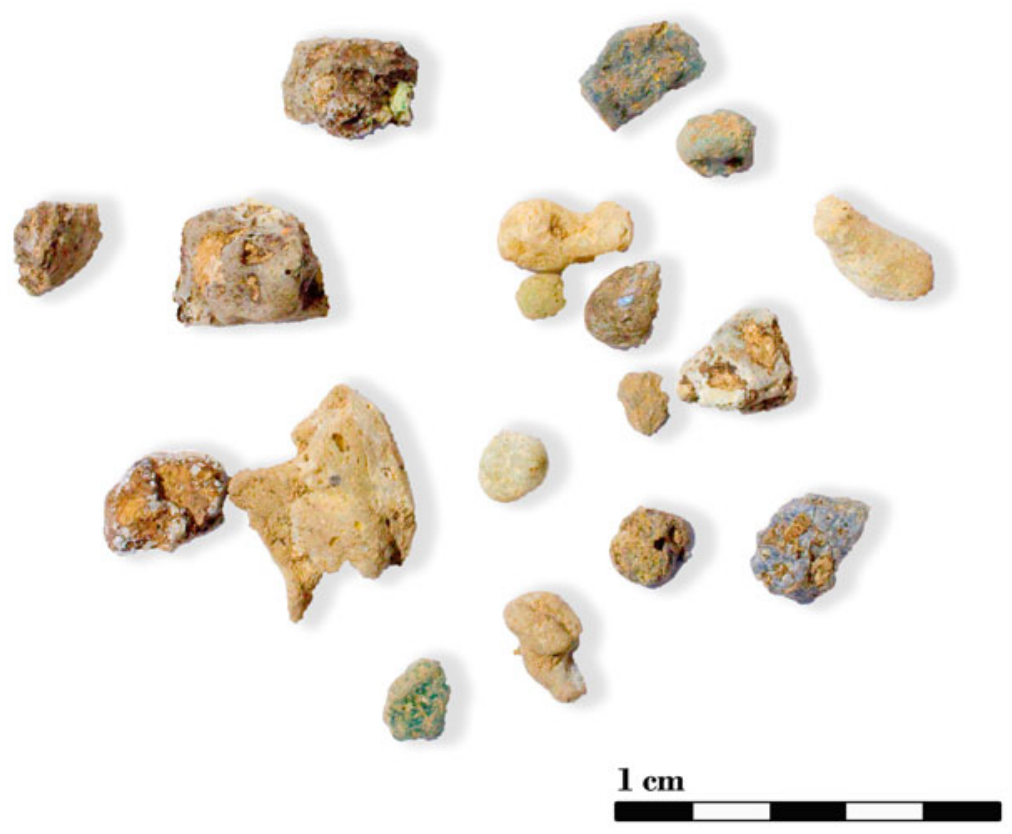

Figure 3. Glass lumps and mosaic tesserae deformed from the heat of the furnace retrieved from the dump outside the villa (Area 7000).

chemical analysis (Figure 4). The cleaned but unprepared samples were analysed by LA-ICP-MS (laser ablation coupled with inductive plasma mass spectrometry) at IRAMAT-CEB in Orléans (France), using a Resonetics M50E excimer $193 \mathrm{~nm}$ laser and a Thermo Fischer Scientific ELEMENT XR mass spectrometer. The analyses were conducted with $5 \mathrm{~mJ}$ energy, $10 \mathrm{~Hz}$ pulse frequency and a beam diameter that ranges from 30 to $100 \mu \mathrm{m}$ depending on the transition metals and particles present in the glass (Gratuze, 2013).

\section{Typology and forming technology}

The current literature on the typology of beads circulating during the Roman Empire and the early Middle Ages is very limited, but sufficient to place the Aiano beads in a geographical and chronological framework. While the Aiano beads are clearly different from the types circulating in Migration-period Europe (Callmer, 1977; Burgmann, 2004; Boschetti et al., 2020a), they are reminiscent of Roman and Late Antique types (Mandruzzato \& Marcante, 2008). From the point of view of the forming technique, the corpus of Aiano beads only contains wound and segmented beads, two of the four forming techniques documented in the ancient Mediterranean (Figure 4). Drawn, coldcut, hot-polished, and mosaic beads are absent.

The majority of the Aiano beads ( $\mathrm{n}=$ 17) and the pendant (TCC09) were made by winding. Three small, monochrome beads (TCC01, 05, 015) can be identified with types that were popular from the third to the sixth century and imitate precious stones (Swift, 2003). One light blue bead (TCC04) of this group belongs to a type well documented in Egypt and Nubia 


\section{WOUND}

\section{Roman}
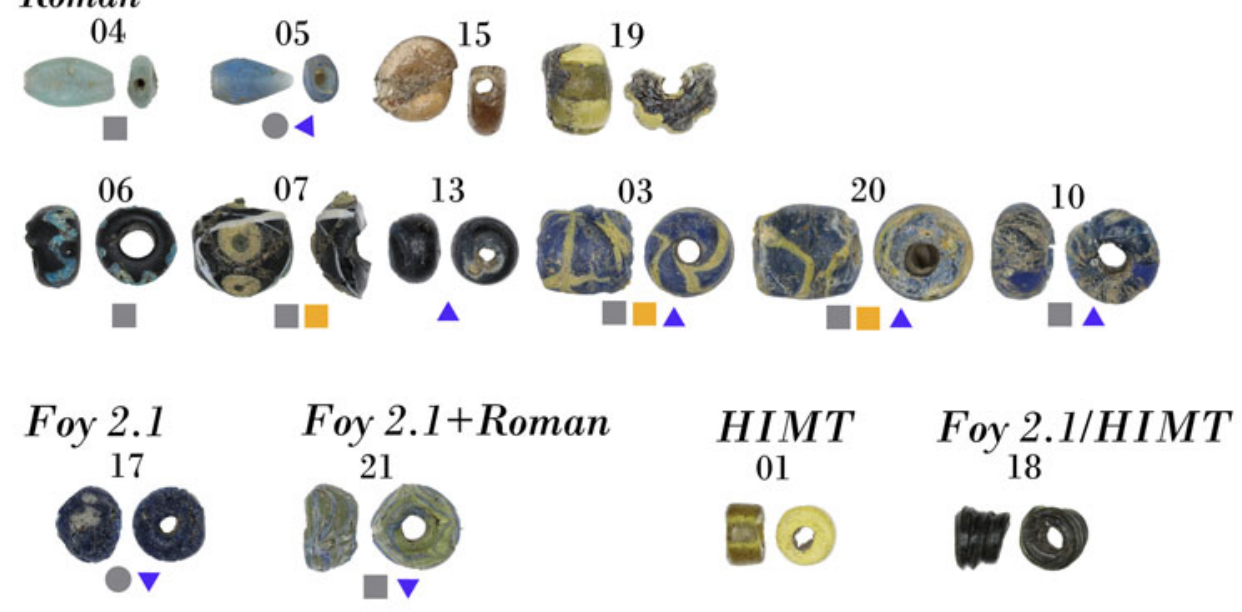

\section{Foy 2.1/HIMT+Roman}
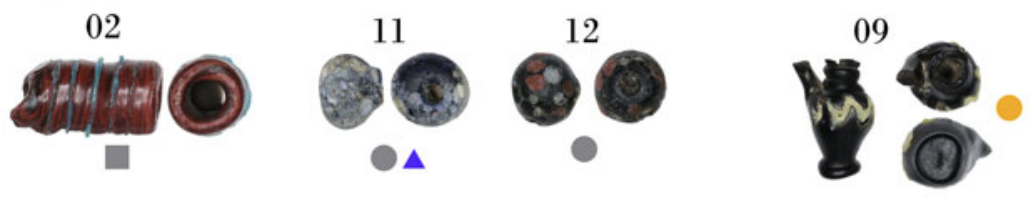

\section{DRAWN-SEGMENTED}

\section{Foy 2.1}

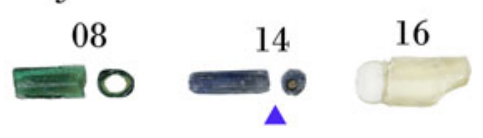

\begin{tabular}{l}
\hline COLOURANTS AND OPACIFIERS \\
Sb opacifier (white) \\
Sb opacifier (yellow) \\
Sn opacifier (white) \\
Sn opacifier (yellow) \\
A Roman Co \\
Vlate Co \\
4 undetermined Co \\
\hline
\end{tabular}

Figure 4. The Aiano beads, divided by forming technique and base glass composition, with indication of the sample number, cobalt source, yellow and white opacifiers.

from the fourth to the sixth century (Then-Obłuska, 2018; Then-Obłuska \& Wagner, 2017). Such beads were often mounted in gold or bronze jewellery in combination with real stones. Seven beads and the pendant TCC09 from Aiano are distinguished by the black glass from which their body was made (TCC06, 07, $11,12,13,17,18)$. This type of glass was particularly appreciated for making ornaments from the third to the fifth century (Cosyns, 2011). The black bead with red, white, and light blue mottled decoration (TCC12) finds parallels in the Late 
Antique burials of the Fayoum and in the jewellery workshop excavated in the Diana quarter in Alexandria (Boschetti et al., 2020a: 12, with references; Rifa-Abou El Nil \& Calligaro, 2020). Similar beads have been recorded in Italy from the first to the fifth century (Mandruzzato \& Marcante, 2008: 4, 158). The workshop of the Diana quarter also offers a parallel for the spiral bead TCC18. Jug-shaped pendants, like an exemplar from Aiano (TCC09), are attested in the Levant and Egypt and were quite popular in the Italian peninsula during the second half of the fourth and the first half of the fifth century (Mandruzzato \& Marcante, 2008: 4, 36-37, 74-75; Bolla, 2011; Mandruzzato, 2017). They are usually interpreted as Christian amulets, and often deposited in burials of women and children (Spaer et al., 2001: 171; Bolla, 2011: 33). A possible Egyptian origin can be assumed for the bead TCC21 since its shape and decoration corresponds to Late Antique Egyptian spindle whorls (Spaer et al., 2001: 259-61).

Interestingly, the few publications on Roman beads tend to identify them as products that circulated locally or on a regional scale (Burgmann, 2004; Mandruzzato \& Marcante, 2008). However, looking at the beads from a broad geographic perspective, the scenario changes radically. For example, a bead from Aquileia, identical to the large, spherical black bead TCC07 decorated with crossed white trails and green and yellow eyes, is dated to the fourth to fifth century on the basis of parallels from present-day Austria, which is assumed to be its place of origin (Mandruzzato \& Marcante, 2008: 64). Other examples of this type were recovered from British burials of the middle of the fifth to the first quarter of the sixth century, where they are thought to be locally produced (Burgmann, 2004: 77, 92). In the 1970s, Margaret Guido discussed the circulation of this type of bead in Britain and noticed some matching parallels in fourth- to fifth-century continental contexts, classifying this type as an exotic Roman product imported from mainland Europe (Guido, 1978: 101-02, 232). A specimen excavated from a thirdcentury burial in Classe, the port city of Ravenna, and associated with black beads decorated with coloured zig-zag trails, similar to Aiano bead TCC06, is evidence of an earlier circulation of this type in Italy (Montevecchi, 2000). Other wound beads from Aiano, like the melon bead TCC19, or the cylindrical beads TCC02, 03, and 20 , belong to very common types, and their date cannot be safely established on typological grounds.

Only three monochrome beads are drawn and segmented (TCC08, 14, 16). The green bead TCC08 is furthermore finished by hot polishing, as occasionally documented in beads of this kind (Spaer, 1993). Drawn beads of this type are Egyptian products, popular in Europe since Late Antiquity, with a major diffusion from the fourth century AD onwards.

\section{Chemical composition}

To further refine the chronology and provenance of the glass beads from Aiano, we can draw on the chemical analysis of the glass (Supplementary Material Table S1). Ancient glass can be classified into different primary production groups, according to the nature of the raw materials used by the glassmakers. From the Hellenistic period up to the ninth century $\mathrm{AD}$, the dominant trend in Mediterranean glassmaking was the use of natron as the main fluxing agent (Shortland et al., 2006). Indeed, all the beads and the pendant from Aiano are natron type glasses with low $\mathrm{MgO}$ and $\mathrm{K}_{2} \mathrm{O}$ concentrations $(<2 \%$ wt). Several samples have higher 


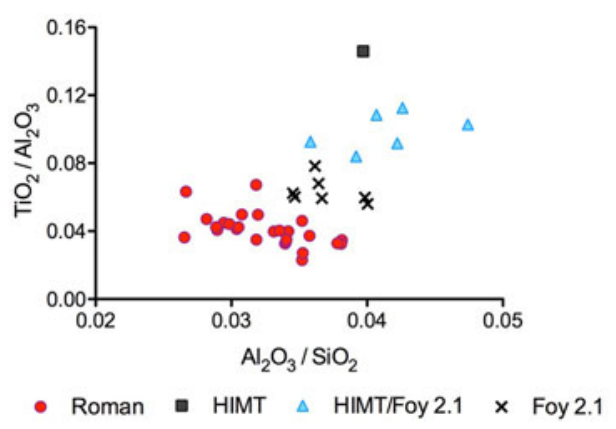

Figure 5. Base glass characteristics of the Aiano beads, separated as a function of $\mathrm{Al}_{2} \mathrm{O}_{3} / \mathrm{SiO}_{2}$ and $\mathrm{TiO}_{2} / \mathrm{Al}_{2} \mathrm{O}_{3}$ ratios.

phosphorus and elevated potassium oxides, with lower chlorine contents. These features are markers of pollution probably due to recycling and/or extended secondary working (Schibille \& Freestone, 2013; Jackson \& Paynter, 2016). The different compositional groups of first-millennium natron glasses can be distinguished on the basis of the ratios of $\mathrm{Al}_{2} \mathrm{O}_{3} / \mathrm{Si}_{2} \mathrm{O}$ and $\mathrm{TiO}_{2} / \mathrm{Al}_{2} \mathrm{O}_{3}$ that reflect the heavy mineral and feldspar contents of the silica source (Freestone et al., 2018). The glasses used for the Aiano beads are broadly consistent with three major compositional groups (Figure 5). Most samples $(\mathrm{n}=26)$ correspond to Roman glass made and circulating throughout the Roman Empire from the first to the third century (Jackson, 2005; Silvestri et al., 2008; Paynter \& Jackson, 2019). Antimony or manganese were often added directly during the primary production in their capacity as decolourizers. The addition of manganese was typical of Levantine glass making, while antimony was preferred in Egypt. The $\mathrm{Na}_{2} \mathrm{O} / \mathrm{SiO}_{2}$ and $\mathrm{CaO} / \mathrm{Al}_{2} \mathrm{O}_{3}$ ratios in Roman glasses can be used to distinguish Egyptian antimony-decolourized from Levantine manganese-decolourized glass because it is currently believed that Roman and Late Antique glass made in Egypt has a higher soda and lower lime content than

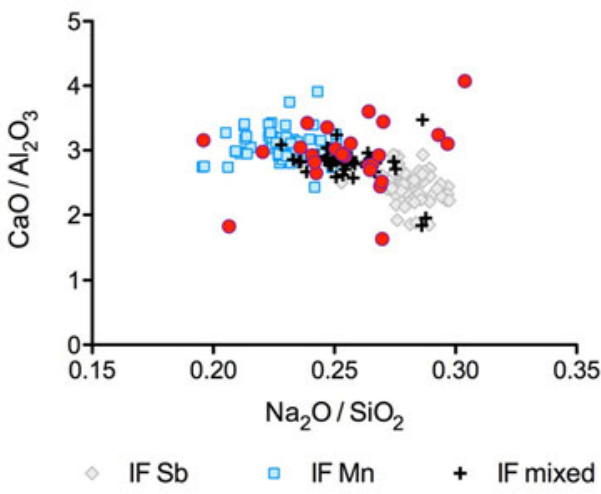

Figure 6. $\mathrm{Na}_{2} \mathrm{O} / \mathrm{SiO}_{2}$ and $\mathrm{CaO} / \mathrm{Al}_{2} \mathrm{O}_{3}$ ratios of the Roman samples from Aiano, compared to different Roman glass reference groups (Roman Sb, Roman Mn, Roman mixed), based on the glass finds from the Iulia Felix shipwreck (IF) (data source: Silvestri, 2008; Silvestri et al., 2008).

contemporary Levantine glass (Jackson, 2005; Freestone, 2015, 2020). With a few exceptions, the Aiano Roman glasses appear to represent a mixture of recycled Roman $\mathrm{Sb}$ and $\mathrm{Mn}$ glasses (Figure 6).

A second group $(n=7)$, with higher $\mathrm{TiO}_{2} / \mathrm{Al}_{2} \mathrm{O}_{3}$ can be identified as belonging to the so-called Foy 2.1 group, named after Danièle Foy, who identified it (Foy et al., 2003) (Figure 5). This compositional group is widely distributed in Europe and North Africa from the second half of the fifth to the seventh century and is of Egyptian origin (Foy et al., 2003; Freestone et al., 2018; De Juan Ares et al., 2019; Barfod et al., 2020). A third group $(\mathrm{n}=6)$, with even higher $\mathrm{TiO}_{2} / \mathrm{Al}_{2} \mathrm{O}_{3}$ ratios resembles HIMT (High Iron, Manganese, and Titanium) glass made in Egypt during the fourth and fifth centuries (Freestone et al., 2018, with references). However, these samples have exceptionally high iron contents that would have augmented the titanium oxide levels and thus may be closer to Foy 2.1 (Figure 5, Table S1). Finally, one sample, with the highest $\mathrm{TiO}_{2} / \mathrm{Al}_{2} \mathrm{O}_{3}$, has the typical values of HIMT glass (Figure 5). 
The identification of the colouring technology underlying the Aiano beads can serve as an additional chronological marker (Figure 4). The majority of the Roman glasses are opacified with calcium and lead antimonate that were commonly used until the fourth century $\mathrm{AD}$ (Boschetti et al., 2020b, with references). The transition to tin-based compounds is documented systematically from the fourth century, and this change emerged first in the eastern Mediterranean (Tite et al., 2008). This new technology underlies one yellow (TCC9) and two Roman white glasses (TCC 11, 12), and one sample of the Foy 2.1 group (TCC17). The cobaltbearing raw materials can similarly serve as a temporal marker in so far as the high $\mathrm{Co} / \mathrm{Ni}$ ratios typical of Roman glasses decrease over time (Gratuze et al., 2018). In all, with the exception of two of the Aiano Roman glass beads (TCC05, 21), the cobalt to nickel ratios are indeed high (Figure 7). The later cobalt signature can be detected in all Foy 2.1 samples except one (TCC14) (Figure 7).

\section{Chronology and Provenance}

The relationships between base glass, forming technology, typology, and, in polychrome beads, the combination of different base glasses, colourants, and opacifiers are useful to establish their relative chronology and provenance. The chemical composition is particularly helpful for the chronology of the monochrome wound beads because they are difficult to date on typological grounds. Four beads are made with Roman glass: the colourless melon bead TCC19 and three drop-shaped beads (TCC04, 05, 15). In the opaque green bead $\mathrm{TCC} 04$, the association of Roman base glass with calcium antimonate as an opacifier supports a date not later than the fourth century. By contrast, the blue bead TCC05 is opacified by tin oxide and is most likely to be a post-fourth century artefact. The spiral black bead TCC18 is made of Foy 2.1/HIMT glass and can be matched with similar black beads probably made in Egypt during the fourth and fifth centuries (Cosyns, 2011). A similar date can be proposed for the simple barrel-shaped colourless bead TCC01 made from HIMT glass.

The polychrome wound beads can be divided into two groups. The first group includes six beads (TCC03, 06, 07, 10, 13, 20), all made with recycled Roman glass, antimony-based opacifiers, and Roman cobalt with a high $\mathrm{Co} / \mathrm{Ni}$ ratio (TCC13). These criteria imply a date probably in the fourth century at the latest. Two beads (TCC06, 07) with typological parallels from the third century, may be residual, originating from the first phase of the villa. A second group, including four beads (TCC02, 11, 12, 21) and the pendant TCC09, combines Foy 2.1 and HIMT glass for the body and recycled Roman glass for the decoration of the beads. The green Roman glass thread applied on the HIMT/Foy 2.1 red bead TCC02 is opacified by calcium antimonate. In the other beads of this group and in the pendant TCC09, the Roman glass is opacified by tin oxide (TCC11, 12) calcium antimonate (21) and lead stannate (TCC09). Roman cobalt is present in the Foy 2.1 translucent body of one mottled bead (TCC11). The Roman blue thread of the bead TCC21, opacified by calcium antimonate, is coloured by a late source of cobalt. Finally, one blue mottled bead (TCC17) is entirely made of Foy 2.1 glass. The translucent blue body is coloured by a post-fourth century cobalt raw material, and the white dots are opacified by tin oxide. This is the only bead where the base glass, the cobalt raw material, and the opacifier point to a date not earlier than the 


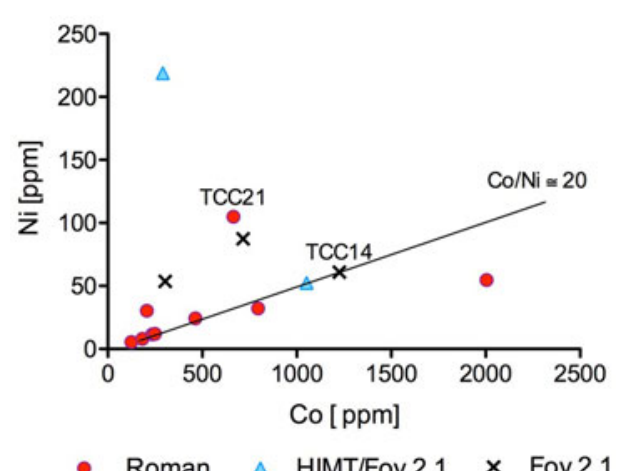

Figure 7. Cobalt relative to nickel concentrations distinguish Roman from Late Antique cobalt sources and confirm the chronological separation of the Roman, Foy 2.1, and Foy 2.1/HIMT glasses used in the Aiano beads.

middle of the fifth century. The Egyptian base glass compositions and the typological parallels support the hypothesis that the Aiano beads were imported from Egypt. This interpretation is highly probable especially for the three mottled beads (TCC11, 12, 17), the bead/spindle whorl TCC21, and the jug-shaped pendant TCC09.

The three drawn-segmented beads (TCC8, 14, and 16) are made with Foy 2.1 glass. Both the base glass and the forming technology lead us to identify these beads as Egyptian products, manufactured between the fifth and the seventh century. The Roman cobalt identified in the blue bead TCC14 suggests a date during the earliest phase of circulation of the Foy 2.1 base glass, in the middle of the fifth century. The distribution of the findspots of the beads, divided by chemical composition and forming technology, does not reveal significant clustering. The exception are the three drawn-segmented beads that were found in contexts connected by a direct stratigraphic correlation. These three beads might have been strung together, but there are too few elements to demonstrate this hypothesis (Figure 2).

\section{Conclusions}

The re-analysis of the corpus of the Aiano glass beads changes their interpretation, date, and connection to the villa and the glass-recycling infrastructures investigated there. The stratigraphic position of the beads and the lack of archaeological indicators of bead production at Aiano rule out a local production during the reoccupation of the building. The results of the typological, technological, and chemical analyses establish a direct link with the life of the villa during its main period of prosperity. The middle of the fourth to the fifth century $\mathrm{AD}$, to which the majority of the beads and the pendant belong, was the period in which the building underwent a fundamental monumentalization. It can be reasonably assumed that the Aiano beads were ornaments worn by the people who lived in the villa before it was abandoned. A few beads can be dated to as early as the middle of the third century and can be assigned to the first phase of the building. All the drawn beads and at least half the wound beads and the pendant are imports, probably from Egypt. Rather than being local products, the Aiano beads are objects obtained through an exchange network operating at a Mediterranean and European level. Beads travelled exceptionally long distances in the period between the Bronze Age and the Iron Age, and, later, during the Migration period. Contrary to previous perceptions of Roman beads as generally worthless products, produced and consumed locally, the clear identification of exotic beads among the finds from Aiano leads to a necessary re-assessment of the status of Roman glass beads in terms of their aesthetic, economic, and symbolic value. While the international dimension of the bead trade during the Roman and Late Antique period or the extent of 
its market is currently far from understood, the results obtained for the Aiano group support a model of long-distance exchange.

\section{Supplementary Material}

To view supplementary material for this article, please visit https://doi.org/10.1017/ eaa.2021.34.

\section{ACKNOWLEDGMents}

This project has received funding from the European Research Council under the European Union's Horizon 2020 research and innovation programme (grant no. 647315 to Nadine Schibille). The 'Regio VII, The Elsa Valley during the Roman Age and Late Antiquity' project has received funding from the Belgian Fund for Scientific Research (FSR-FNRS) and the municipality of San Gimignano in Italy. For help with storage in San Gimignano and archaeological and topographical drawing, we would like to thank Dr Gloriana Pace and Dr Alessandro Novellini. For the excavation of the villa of Aiano, we are grateful to the Soprintendenza Archeologia, Belle Arti e Paesaggio of Siena, Grosseto and Arezzo. The funding organizations have had no influence in the study design, data collection, analysis, decision to publish, or preparation of this manuscript.

\section{REFERENCES}

Barfod, G.H., Freestone, I.C., Lesher, C.E., Lichtenberger, A. \& Raja, R. 2020. 'Alexandrian' Glass Confirmed by Hafnium Isotopes. Scientific Reports, 10: 11322. https://doi.org/10.1038/s41598-020-68089-w

Bezborodov, M.A. 1959. Glasherstellung bei den slawischen Völkern an der Schwelle des Mittelalters. Wissenschaftliche Zeitschrift der Humboldt-Universität zu Berlin, 8: 187-93.

Bianchi, R.S. 1983. Those Ubiquitous Glass Inlays. Journal of Glass Studies, 25: 29-35.

Bolla, M. 2011. Clastidium e l'area Pleba. In: R. Invernizzi, ed. ...Et in memoriam eorum. La necropoli romana dell'area Pleba di Casteggio:. Casteggio: Commune di Casteggio, pp. 39-269.

Boschetti, C. 2020. Vetro e blu egizio nel Ninfeo di Segni: aspetti decorativi, tipologici e tecnologici. In: F.M. Cifarelli, ed. Il Ninfeo di Q. Mutius a Segni. Rome: Quasar, pp. 55-67.

Boschetti, C., Gratuze, B. \& Schibille, N. 2020a. Commercial and Social Significance of Glass Beads in Migration-Period Italy: The Cemetery of Campo Marchione. Oxford Journal of Archaeology, 39: 319-42. https://doi.org/10.1111/ojoa.12200

Boschetti, C., Leonelli, C., Rosa, R., Romagnoli, M., Ángel, M., Tévar, V. \& Schibille, N. 2020b. Preliminary Thermal Investigations of Calcium Antimonate Opacified White Glass Tesserae. Heritage, 2: 549-60. https://doi.org/10. 3390/heritage3020032

Boschetti, C., Mantovani, V. \& Leonelli, C. 2016. Glass Coloring and Recycling in Late Antiquity: A New Case Study from Aquileia (Italy). Journal of Glass Studies, 58: 69-86.

Burgmann, B. 2004. Glass Beads from Early Anglo-Saxon Graves: A Study of the Provenance and Chronology of Glass Beads from Early Anglo-Saxon Graves, Based on Visual Examination. Oxford: Oxbow.

Callmer, J. 1977. Trade Beads and Bead Trade in Scandinavia, ca 800-1000 AD (Acta archaeologica Lundensia Series in $\left.4^{\circ}, 11\right)$. Lund: Gleerup \& Bonn: Habelt.

Cavalieri, M. 2013. Quid igitur est ista villa? L'Etruria centro-settentrionale tarda Antichità e alto Medioevo. Nuovi dati e vecchi modelli a confronto sulla villa d'Aiano-Torraccia di Chiusi. In: G. Schörner, ed. Leben auf dem Lande. II Monte' bei San Gimignano. Ein römischer Fundplatz und sein Kontext. Vienna: Phoibos, pp. 283-319.

Cavalieri, M. 2020. Investigating Transformations through Archaeological Records in the Heart of Tuscany: The Roman Villa at Aiano between Late Antiquity and the Early 
Middle Ages. In: P. Cimadomo, R. Palermo, R. Pappalardo \& R. Pierobon Benoit, eds. Before/After: Transformation, Change, and Abandonment in the Roman and Late Antique Mediterranean. Oxford: Archaeopress, pp. 97-113.

Cavalieri, M. \& Giumlia-Mair, A. 2009. Lombardic Glassworking in Tuscany. Materials and Manufacturing Processes, 24: 1023-32. https://doi.org/10.1080/1042691 0902987119

Cavalieri, M. \& Peeters, A. 2020. Dalla villa al cantiere. Vivere in Toscana tra tarda Antichità ed alto Medioevo: la villa d'Aiano (Siena). In: M. Cavalieri \& F. Sacchi, eds. La villa dopo la villa. Trasformazione di un sistema insediativo ed economico in Italia centro-settentrionale tra tarda Antichità e Medioevo. Louvain: Presses Universitaires de Louvain, pp. 61-78.

Cavalieri, M., Baldini, G., Giumlia-Mair, A., Montevecchi, N., Novellini, A. \& Ragazzini, S. 2009. San Gimignano (SI). La villa di Torraccia di Chiusi, località Aiano. Dati ed interpretazioni dalla V campagna di scavo, 2009. Notiziario della Soprintendenza per $i$ Beni archeologici della Toscana: 492-517.

Cavalieri, M., Camin, L. \& Paolucci, F. 2016. I sectilia vitrei dagli scavi della villa romana di Aiano-Torraccia di Chiusi (Siena, Toscana). Journal of Glass Studies, 58: 286-91.

Cavalieri, M., Lenzi, S. \& Cantisani, E. 2013. La fine della villa tardoantica di AianoTorraccia di Chiusi (San Gimignano, Siena): la sistematica distruzione dei suoi arredi. Nuovi dati archeologici su litotipi e sistemi decorativi. In: C. Angelelli, ed. Atti del XVIII colloquio dell'associazione italiana per lo studio e la conservazioen del mosaico. Tivoli: Ante Quem, pp. 537-44.

Cavazzuti, C., Cardarelli, A., Quondam, F., Salzani, L., Ferrante, M., Nisi, S., et al. 2019. Mobile Elites at Frattesina: Flows of People in a Late Bronze Age 'Port of Trade' in Northern Italy. Antiquity, 93: 624-44. https://doi.org/10.15184/aqy.2019.59

Conte, S., Arletti, R., Mermati, F. \& Gratuze, B. 2016. Unravelling the Iron Age Glass Trade in Southern Italy: The First TraceElement Analyses. European Journal of Mineralogy, 28: 847-51. https://doi.org/10. 1127/ejm/2016/0028-2572
Conte, S., Matarese, I., Vezzalini, G., Pacciarelli, M., Scarano, T., Vanzetti A., et al. 2019. How Much Is Known About Glassy Materials in Bronze and Iron Age Italy? New Data and General Overview. Archaeological and Anthropological Sciences, 11: 1813-41. https://doi.org/10.1007/ s12520-018-0634-6

Cosyns, P. 2011. The Production, Distribution and Consumption of Black Glass in the Roman Empire During the 1st-5th Century AD: An Archaeological, Archaeometric and Historical Approach (unpublished $\mathrm{PhD}$ dissertation, Free University of Brussels).

De Juan Ares, J., Vigil-Escalera Guirado, A., Cáceres Gutiérrez, Y. \& Schibille, N. 2019. Changes in the Supply of Eastern Mediterranean Glasses to Visigothic Spain. Journal of Archaeological Science, 107: 23-31. https://doi.org/10.1016/j.jas.2019. 04.006

Deltenre, F.-D. \& Orlandi, L. 2016. « Rien ne se perd, rien ne se crée, tout se transforme ». Transformation and Manufacturing in the Late Roman Villa of Aiano-Torraccia di Chiusi (5th-7th Century AD) - Villa romana di Aiano-Torraccia di Chiusi. Postclassical Archaeologies, 6: 71-90.

Feldman, M. 2006. Diplomacy by Design: Luxury Arts and an 'International Style' in the Ancient Near East, 1400-1200 $B C E$. Chicago (IL): University of Chicago Press.

Foy, D., Picon, M., Vichy, M. \& Thirion Merle, V. 2003. Caractérisation des verres de la fin de l'Antiquité en Méditerranée occidentale : l'émergence de nouveaux courants commerciaux. In: D. Foy \& M.D. Nenna, eds. Échanges et commerce du verre dans le monde antique. Actes du Colloque de l'Association française pour l'archéologie du verre, Aix-en-Provence et Marseille, 7-9 juin 2001. Montagnac: Monique Mergoil, pp. 41-85.

Francis, P. Jr 1988. Glass Beads in Asia. Part I. Introduction. Asian Perspectives (Honolulu), 28: 1-21.

Francis, P. Jr 1990. Glass Beads in Asia, Part II: Indo-Pacific Beads. Asian Perspectives (Honolulu), 29: 1-23.

Freestone, I.C. 2015. The Recycling and Reuse of Roman Glass: Analytical Approaches. Journal of Glass Studies, 57: 29-40. 
Freestone, I.C. 2020. Apollonia Glass and its Markets: An Analytical Perspective. In: O. Tal, ed. Apollonia-Arsuf, Final Report of the Excavations, 2: Excavations Outside the Medieval Town Walls. Winona Lake (IN): Eisenbrauns, pp. 341-48.

Freestone, I.C., Degryse, P., Lankton, J., Gratuze, B. \& Schneider, J. 2018. HIMT, Glass Composition and Commodity Branding in the Primary Glass Industry. In. M.P. Rosenow, A. Meek \& I.C Freestone, eds. Things that Travelled: Mediterranean Glass in the First Millennium $A D$. London: UCL Pres, pp. 159-90.

Gleba, M. 2017. Tracing Textile Cultures of Italy and Greece in the Early First Millennium BC. Antiquity, 91: 1205-22. https://doi.org/10.15184/aqy.2017.144

Gratuze, B. 2013. Glass Characterisation Using Laser Ablation Inductively Coupled Plasma Mass Spectrometry Methods. In: K. Janssens, ed. Modern Methods for Analysing Archaeological and Historical Glass, 1: 201-34. https://doi.org/10.1002/ 9781118314234.ch9

Gratuze, B., Pactat, I. \& Schibille, N. 2018. Changes in the Signature of Cobalt Colorants in Late Antique and Early Islamic Glass Production. Minerals, 8: 225. https://doi.org/10.3390/min8060225

Guido, M. 1978. The Glass Beads of the Prehistoric and Roman Periods in Britain and Ireland. London: Thames \& Hudson.

Hodgkinson, A. 2017. Technology and Urbanism in Late Bronze Age Egypt (Oxford Studies in Egyptology, 1). Oxford: Oxford University Press.

Jackson, C.M. 2005. Making Colourless Glass in the Roman Period. Archaeometry, 47: 763-80. https://doi.org/10.1111/j.14754754.2005.00231.x

Jackson, C.M. \& Nicholson, P.T. 2010. The Provenance of Some Glass Ingots from the Uluburun Shipwreck. Journal of Archaeological Science, 37: 295-301. https:// doi.org/10.1016/j.jas.2009.09.040

Jackson, C.M. \& Paynter, S. 2016. A Great Big Melting Pot: Exploring Patterns of Glass Supply, Consumption and Recycling in Roman Coppergate, York*. Archaeometry, 58: 68-95. https://doi.org/ 10.1111/arcm.12158

Juwig, C. 2010. Die Gewandreliquie der heiligen Bathilde. Überlegungen zur ihrem
Bildstatus und Funktionskontext. In: C. Juwig \& C. Kost, eds. Bilder in der Archäologie -Archäologie der Bilder? (Tübinger Archäologische Taschenbücher, 8). Münster, New York, München \& Berlin: Waxmann, pp. 197-211.

Liu, R.K., Holland, S. \& Holland, T. 2017. Ancient Nubian Face Beads: The Problem with Suppositions. Ornament, 40(2): 34-39.

Mandruzzato, L. 2017. Vetro. In: F. Fontana, ed. Scavi ad Aquileia III. Aquileia, l'insula tra foro $e$ porto fluviale: lo scavo dell'Università degli Studi di Trieste 1, la strada. Trieste: Editreg, pp. 293-301.

Mandruzzato, L. \& Marcante, A. 2008. Vetri antichi del Museo Archeologico Nazionale di Aquileia. Ornamenti, oggettistica e vetro pre-e post-romano (Corpus delle Collezioni del Vetro in Friuli Venezia Giulia, 4). Roma: Arbor Sapientiae.

Montevecchi, G. 2000. Corredo funerario, Classe (Ravenna), via Romea sud, podere Giorgioni, tomba 29. In: M. Marini Calvani, ed. Aemilia. La cultura romana in Emilia Romagna dal III secolo a. C. all'età costantiniana. Venezia: Marsilio, pp. 159-61.

Moorey, P.R.S. 1994. Ancient Mesopotamian Materials and Industries: The Archaeological Evidence. Oxford: Clarendon Press.

Müller, M. 2018. Foundation Deposits and Strategies of Place-Making at Tell elDab'a/Avaris. Near Eastern Archaeology, 81: 182-90. https://doi.org/10.5615/neareastarch.81.3.0182

Nenna, M.-D. 1993. La verrerie d'époque hellénistique à Délos. Journal of Glass Studies, 35: 11-21.

Nightingale, G. 2008. Tiny, Fragile, Common, Precious: Mycenaean Glass and Faience, Beads and Other Objects. In: C. Jackson \& E.C. Wagner, eds. Vitreous Materials in the Late Bronze Age Aegean. Oxford: Oxbow Books, pp. 64-104.

Paynter, S. \& Jackson, C. 2019. Clarity and Brilliance: Antimony in Colourless Natron Glass Explored Using Roman Glass Found in Britain. Archaeological and Anthropological Sciences, 11: 1533-51. https:// doi.org/10.1007/s12520-017-0591-5

Pion, C. \& Gratuze, B. 2016. Indo-Pacific Glass Beads from the Indian Subcontinent in Early Merovingian Graves (5th-6th Century AD). Archaeological Research in 
Asia, 6: 51-64. https://doi.org/10.1016/j. ara.2016.02.005

Pulak, C. 1998. The Uluburun Shipwreck: An Overview. The International Journal of Nautical Archaeology 27: 188-224. https:// doi.org/10.1016/s1057-2414(98)80031-9

Rifa-Abou El Nil, P. \& Calligaro, T. 2020. Un atelier de taille de pierre semiprécieuses à Alexandrie. In: M.-T. DinhAudouin, D. Olivier \& P. Rigny, eds. Chimie et Alexandrie dans l'Antiquité. Les Ulis: EDP Sciences, pp. 247-66.

Rodziewicz, M. 1984. Les habitations romaines tardives d'Alexandrie à la lumière des fouilles polonaises a Kom el-Dikka. Warsav: PWN, Éditions Scientifiques de Pologne.

Schibille, N. \& Freestone, I.C. 2013. Composition, Production and Procurement of Glass at San Vincenzo al Volturno: An Early Medieval Monastic Complex in Southern Italy. PLOS ONE, 8: e7647. https://doi.org/10.1371/journal.pone. 0076479

Sebastiani, A. 2016. Glass and Metal Production at Alberese: The Workshops and the Manufacturing District of Spolverino. Postclassical Archaeologies, 6: 63-70.

Sebastiani, A. \& Derrick, T.J. 2020. A Regional Economy of Recycling over Four Centuries at Spolverino (Tuscany) and Environs. In: C.N. Duckworth \& A. Wilson, eds. Recycling and Reuse in the Roman Economy. Oxford: Oxford University Pres, pp. 359-82.

Shortland, A. 2000. Vitreous Materials at Amarna: The Production of Glass and Faience in 18th Dynasty Egypt (BAR International Series 827). Oxford: British Archaeological Reports.

Shortland, A., Schachner, L., Freestone, I. \& Tite, M. 2006. Natron as a Flux in the Early Vitreous Materials Industry: Sources, Beginnings and Reasons for Decline. Journal of Archaeological Science, 33: 521-30. https:// doi.org/10.1016/j.jas.2005.09.011

Silvestri, A. 2008. The Coloured Glass of Iulia Felix. Journal of Archaeological Science, 35: 1489-1501. https://doi.org/10.1016/j.jas. 2007.10.014

Silvestri, A., Molin, G. \& Salviulo, G. 2008. The Colourless Glass of Iulia Felix. Journal of Archaeological Science, 35: 331-41. https:// doi.org/10.1016/j.jas.2007.03.010
Spaer, M. 1993. Gold-Glass Beads: A Review of the Evidence. BEADS: Journal of the Society of Bead Researchers, 5: 9-25. https:// surface.syr.edu/beads/vol5/iss1/5

Spaer, M., Barag, D., Ornan, T. \& Neuhaus, T. 2001. Ancient Glass in the Israel Museum: Beads and Other Small Objects. Jerusalem: Israel Museum.

Swift, E. 2003. Late-Roman Bead Necklaces and Bracelets. Journal of Roman Archaeology, 16: 336-49. https://doi.org/ 10.1017/s1047759400013167

Then-Obłuska, J. 2013. Medieval Transcultural Medium: Beads and Pendants from Makurian and Post-Makurian Dongola in Nubia. Polish Archaeology in the Mediterranean, 22: 679-720.

Then-Obłuska, J. 2017. Beads and Pendants from the Late Harbor Temple and Harbor Temenos in the Red Sea Port of Berenike: Techniques, Functions and Affiliations. Polish Archaeology in the Mediterranean, 26: 193-210.

Then-Obłuska, J. 2018. Beads and Pendants from the Hellenistic to Early Byzantine Red Sea Port of Berenike, Egypt, Season 2014 and 2015. Polish Archaeology in the Mediterranean, 27: 203-33.

Then-Obłuska, J. \& Wagner, B. 2017. Glass Bead Trade in Northeast Africa in the Roman Period. In: S. Wolf \& A. De Pury-Gysel, eds. Annales du 20e Congrès de l'Association internationale pour l'bistoire du verre. Rhaden/Westf: Marie Leidorf, pp. 248-56.

Tite, M., Pradell, T. \& Shortland, A. 2008. Discovery, Production and Use of TinBased Opacifiers in Glasses, Enamels and Glazes from the Late Iron Age Onwards: A Reassessment. Archaeometry, 50: 67-84. https://doi.org/10.1111/j.1475-4754.2007. 00339.x

Towle, A., Henderson, J. \& Bellintani, P. 2001. Frattesina and Adria: Report of Scientific Analyses of Early Glass from the Veneto. Padusa, 37: 7-68.

Varberg, J., Gratuze, B. \& Kaul, F. 2015. Between Egypt, Mesopotamia and Scandinavia: Late Bronze Age Glass Beads Found in Denmark. Journal of Archaeological Science, 54: 168-81. https:// doi.org/10.1016/j.jas.2014.11.036

Weinberg, G.D. 1983. A Hellenistic Glass Factory on Rhodes: Progress Report. Journal of Glass Studies, 25: 37. 


\section{Biographical Notes}

Cristina Boschetti graduated in Curatorial Studies from the University of Parma in 2001 and in Classics from the same university in 2005 , followed by a diploma in Conservation of Paintings from ENAIP, Brescia, in 2004 and a $\mathrm{PhD}$ in Archaeological Science from the University of Padua in 2009. She has since held postdoctoral positions at the universities of Nottingham, Padua, and Cairo. In 2008, she joined the Institut de Recherche sur les Archéomatériaux at the University of Orléans, as researcher on the ERC-funded project GlassRoutes, directed by Nadine Schibille. Her research interests include the study of the economy and technology of glass from the Hellenistic to the medieval eras and of mosaics and wall paintings of these periods, with a focus on workshop practices.

Address: IRAMAT-CEB, UMR5060, CNRS/Université d'Orléans, 3D, rue de la Férollerie, 45071 Orléans cedex 2, France. [email:cristina.boschetti@cnrs-orleans.fr]. ORCiD: https://orcid.org/0000-0003-4499779X.

Bernard Gratuze is director of research at the CNRS, Institut de Recherche sur les Archéomatériaux, University of Orléans. His research interests include the development of analytical protocols using laser ablation inductively coupled plasma mass spectrometry (LA-ICP-MS) for glass (as well as lithic materials) to study their production and trade from protohistory to the modern period. He studies glass making processes and recipes since the beginning of the second millennium $\mathrm{BC}$, with a particular interest for transitions (e.g. change from soda plant ash fluxes to natron in the early first millennium BC, or from natron to forest plant ashes fluxes in the late first millennium $\mathrm{AD}$ ). He recently identified, with colleagues, Indian glass beads imports in early medieval western Europe.

Address: IRAMAT-CEB, UMR5060, CNRS/ Université d'Orléans, 3D, rue de la Férollerie, 45071 Orléans cedex 2, France. [email: bernard.gratuze@cnrs-orleans.fr]. ORCiD: https://orcid.org/0000-0001-6136-8085.

Marco Cavalieri graduated in Classics from the University of Parma, followed by a Specialisation Diploma in Greek and Roman Archaeology from the University of Florence and a $\mathrm{PhD}$ in Archaeology form the University of Perugia. He is full professor of Archaeology and History of Ancient Art at the Universite Catholique of Louvain (UCLouvain, Belgium), where he was appointed in 2003. His main research interests include Roman archaeology, with a focus on urbanism and topography of the Cisalpine region; urbanism, architecture and art, as expressions of the ideology of Roman power; and the archaeology of the Italic world and Roman provinces. $\mathrm{He}$ is director of three UCLouvain archaeological missions in Italy: Aiano since 2005, Cures Sabini, Rieti, since 2014, and Ostia since 2019.

Address: Institut des Civilisations, Arts et Lettres, Université Catholique de Louvain (UCLouvain), Place B. Pascal, 1, Collège Erasme, BP L3.03.13, 1348 Louvain-laNeuve, Belgique. [email: marco.cavalieri@ uclouvain.be]. ORCiD: https://orcid.org/ 0000-0002-9825-1910.

Sara Lenzi obtained an MA in Archaeology from the University of Florence in 2011, with a dissertation on Roman painted marble slabs in the collections of Kunsthistorisches Museum, Vienna. In 
2015 she obtained a $\mathrm{PhD}$ in Archaeology from the University of Florence, a study that investigated the polychromy of the socalled monochromes on marble from Pompeii and Herculaneum. She is an external collaborator at UCLouvain, as a member of the team excavating Aiano. Her main research interests include polychromy on Roman sculpture, Roman wall painting, opus sectile, and the study of spoliation and recycling during the early Middle Ages.

Address: Institut des Civilisations, Arts et Lettres, Université catholique de Louvain (UCLouvain), Place B. Pascal, 1, Collège Erasme, BP L3.03.13, 1348 Louvain-laNeuve, Belgique. [email: sara.lenzi2014@ gmail.com]. ORCiD: https://orcid.org/00000003-4057-3631.

Nadine Schibille obtained her PhD in the History of Art from the University of
Sussex in 2004. During her doctoral research she developed an interdisciplinary strategy to investigate the material and aesthetic aspects of light in the art and architecture of Byzantium. Following an MSc from the Institute of Archaeology at UCL in 2005, Nadine has held postdoctoral positions at Stanford University, the Getty Institute, and the University of Oxford. She joined the CNRS in 2015 as chargé de recherche to lead an ERC2014-CoG project entitled GlassRoutes (ID: 647315) that traces Mediterraneanwide developments in the production, trade, and consumption of glass using scientific methods, in particular LA-ICP-MS.

Address: IRAMAT-CEB, UMR5060, CNRS/Université d'Orléans, 3D, rue de la Férollerie, 45071 Orléans cedex 2, France. [email: nadine.schibille@cnrs-orleans.fr]. ORCiD: https://orcid.org/0000-0001-92420392.

\section{Production ou consommation? Les perles en verre de la villa romaine d'Aiano en Toscane}

Vingt perles en verre, un pendentif et un four de recyclage du verre, interprété dans un premier temps comme celui d'un atelier de fabrication des perles, ont été découverts lors des fouilles de la villa romaine d'Aiano. Dans cet article, l'hypothèse d'une présence d'artisans perliers sur le site de la villa est confrontée à de nouvelles données obtenues grâce aux progrès récents des études effectuées sur les verres archéologiques. L'étude combinée de la typologie des perles, de leur technologie de production et de leur composition chimique met en évidence la présence de deux techniques de façonnage différentes (perles enroulées et tubes étirés et segmentés), et de quatre verres de compositions différentes (Roman, HIMT, Foy 2.1 et Foy 2.1/HIMT). On observe aussi l'emploi de différents matériaux et techniques de coloration et d'opacification (opacification avec l'aide de composés d'étain et d'antimoine et utilisation de deux minerais de cobalt). Ces résultats excluent clairement l'hypothèse d'une production locale des perles et montrent qu'Aiano était intégré au sein d'un large réseau de commerce antique de perles. La plupart des perles qui y ont été trouvées peuvent être attribuées à la phase de monumentalisation de la villa du IVe au Ve siècle, et sont représentatives des éléments de parure portés par ses babitants. Translation by the authors

Mots-clés: perles en verre romaines, four de recyclage du verre, Toscane à la fin de l'Antiquité, commerce du verre romain, villa romaine 


\section{Herstellung oder Konsum? Die Glasperlen aus der römischen Villa von Aiano in der Toskana}

Ausgrabungen in der römischen Villa von Aiano ergaben zwanzig Glasperlen, einen Anbänger und einen Glasrecyclingofen, der ursprünglich als Perlenwerkstatt interpretiert wurde. Dieser Artikel betrachtet erneut die Beweislage im Licht neuer Angaben und berücksichtigt dabei die jüngste Forschung in archäologischen Glasstudien. Eine detaillierte Untersuchung der Typologie, Technologie und chemischen Zusammensetzung der Perlen schließt eine lokale Produktion eindeutig aus. Stattdessen deutet das Vorkommen zweier unterschiedlicher Formgebungstechniken, vier verschiedener Rohgläser (römisch, HIMT, Foy 2.1 und Foy 2.1/HIMT) und zahlreicher Farbstoffe, Trübungsmittel und Techniken auf ein gut etabliertes und weitverzweigtes Netz des römischen Perlenhandels bin, an dem Aiano offensichtlich beteiligt war. Die Mehrzahl der Perlen können mit der Monumentalisierung der Villa im vierten bis fünften Jabrbundert in Zusammenhang gebracht werden und repräsentieren einen Teil der von den Einwohnern getragenen Ornamente. Translation by the authors

Stichworte: römische Glasperlen, Glasrecyclingwerkstatt, Toskana in der Spätantike, römischer Perlenhandel, römische Villa 